\title{
Taxonomic interpretations of Australian native bamboos (Poaceae: Bambuseae) and their biogeographic implications
}

\author{
Donald C. Franklin \\ School for Environmental Research, Charles Darwin University, Darwin NT 0909, Australia \\ Email:don.franklin@cdu.edu.au
}

\begin{abstract}
Australia's three native bamboo species - Bambusa arnhemica, Mullerochloa moreheadiana and Neololeba atra - are restricted to northern Australia. The most parsimonious explanation for the occurrence of bamboo in Australia is that there have been at least three founder events from Asia, but other possibilities exist including an Australian radiation involving Neololeba and Mullerochloa. Bambusa arnhemica may be allied to the Asian B. blumeana which occurs as close as Timor. I summarise historical evidence and biogeographic patterns for B. arnhemica, and describe the flowering wave phenomenon in the species, evidence which collectively suggests that $B$. arnhemica is neither very ancient nor very recent in origin. Current studies of the population genetics of B. arnhemica, and of the relationship between Australian and Asian bamboos, may yield fascinating further biogeographic insights.
\end{abstract}

\section{Introduction}

The tall, gracefully-arching leafy culms of bamboo are not characteristic of the Australian environment and, at a popular level at least, there is some resistance to the notion that any bamboo could be native to the continent. A negative view of bamboos has been reinforced by the invasiveness of several leptomorph (running) temperate-zone Asian species of Phyllostachys Siebold \& Zucc. that are weeds in parts of south-eastern Australia (Lazarides 2002). Australia has three native bamboo species (Mallett \& Orchard 2002) that, being confined to remoter tropical regions of the continent (Fig. 1), are not well known and have received almost no scientific attention until recently.

The three species are Bambusa arnhemica F.Muell., Neololeba atra (Lindl.) Widjaja, and Mullerochloa moreheadiana (F.M.Bailey) K.M.Wong (Table 1). Bambusa arnhemica is a robust, erect, clumping bamboo endemic to the higher rainfall north-west of the Northern

Paper from the Australian Systematic Botany Society Conference held in Darwin, September 2007 
Territory. It grows mainly in riparian forests and occasionally on rocky hillsides and other fire-sheltered non-riparian sites, ranging from Kakadu National Park west and south-west to the Daly River and north to Melville Island, often occurring in monodominant stands (Franklin \& Bowman 2004). Neololeba atra is a slender, clumping, large-leaved species found in scattered locations in rainforest and vine-thicket along the Queensland coast from Mackay to the Torres Strait and also in New Guinea, the Moluccas, northern Sulawesi and the Philippines (Widjaja 1997). Mullerochloa moreheadiana is a rampant, non-twining scrambler endemic to the wet tropics of Queensland (Wong 2005), where it is known from the Innisfail and Daintree areas.

Cusack (1999) and Leu (2001) refer to Schizostachyum sp. 'Murray Island' as a fourth native species from the Torres Strait. However, this record is apparently not supported by herbarium specimens, its generic placement is speculative, and my enquiries suggest the relevant populations are likely to be remnants of disused plantations. On current evidence, these reports cannot be accepted as evidence that the species has established in the wild, let alone that it is a native species.

How did the three species reach Australia and how long have they been here? What is their relationship to Asian bamboos? Are B. arnhemica and M. moreheadiana truly endemic? Do they represent an Australian radiation, separate colonisation events from Asia, or Gondwanan remnants? These questions are necessarily grounded in taxonomic interpretation, and it is only in the past decade that the status of these species has been evaluated with sufficient care to allow the generation of plausible historical biogeographic hypotheses. In this paper,

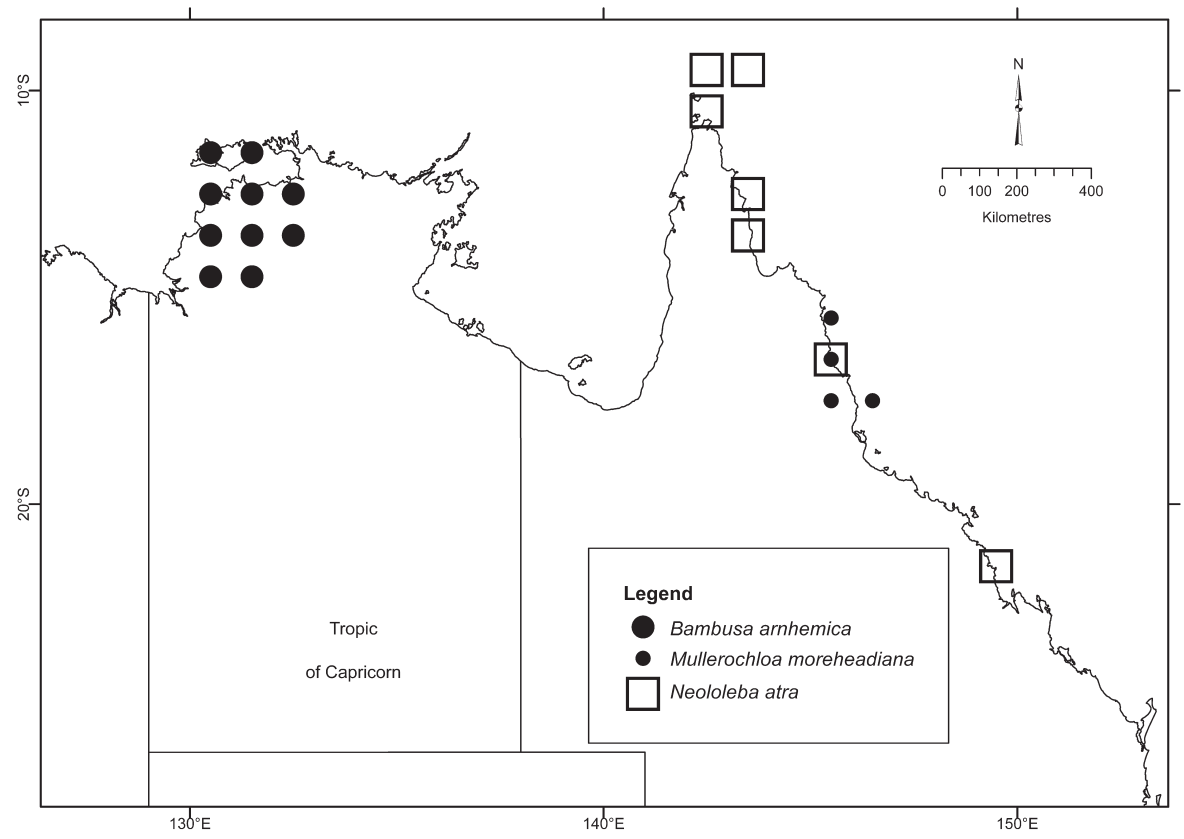

Fig. 1. Distribution of native bamboos in Australia. Data for Bambusa arnhemica are from the dataset underlying the distribution map in Franklin \& Bowman (2004). Data for Neololeba atra and Mullerochloa moreheadiana are from CPBR (2007). 
I will summarise current understandings about the taxonomic status and relationships of Australian native bamboos and briefly explore the emergent biogeographic implications.

\section{Background: 'woody' bamboos}

The 'woody' bamboos (Poaceae: Bambuseae) are a putatively monophyletic sister group to the herbaceous bamboos, tribe Olyreae, which together comprise the Bambusoideae (Zhang \& Clark 2000, Grass Phylogeny Working Group 2001). The vernacular name 'bamboo' can generate confusion and reflects a chequered history of taxonomic interpretation (Clark 1997): in this paper, the term is taken to mean a member of the tribe Bambuseae.

The major centre of diversity is in Asia, especially southern China, with over 1,000 species in the Asia-Pacific region (Bystriakova et al. 2003). A second, lesser centre of diversity is in higher-rainfall tropical and temperate regions of Latin America with c. 430 species (Bystriakova et al.2004). Five species occur naturally in continental Africa, 33 in Madagascar and three in the United States (Bystriakova et al. 2004, Triplett et al. 2006), along with three in Australia. No species occur naturally in Europe, although fossil bamboos have been found in Poland (Worobiec \& Worobiec 2005).

Bamboos are obligately and fundamentally clonal. A feature of many species is a vegetative growth phase that may last decades or even centuries (Janzen 1976). Though at least a few species flower annually, many flower only at the end of this growth phase and either die, or their above-ground parts die, after flowering. Even more intriguing, many semelparous species flower and die synchronously and in spatio-temporal waves. The molecular mechanisms underlying the timing of these events remain "basic biological mysteries" (Judziewicz et al. 1999). A morphological corollary to this behaviour is the iterauctant inflorescence of some species, in which the pseudospikelets bear basal buds and are thus, theoretically, capable of indefinite proliferation. An ecological corollary of gregarious semelparity is a strong tendency for bamboos to occur in monodominant stands (Franklin \& Bowman 2003, Griscom et al. 2007) or, in open forests, as monodominant understoreys (Saitoh et al. 2002, Taylor et al. 2004, Holz \& Veblen 2006).

Probably no other large group of vascular plants is as poorly understood taxonomically as the Bambuseae. Natural selection appears to have favoured vegetative diversification. Key features such as rhizomes, culms, branch buds, branch complements and culm leaves do not fit well on standard herbarium specimen sheets and are not often collected. The flowers of many species are rarely available, and some species have been described without them. An Australian example is that the flowers of M. moreheadiana were first formally described by Clifford (1993), 104 years after the species was described. Furthermore, molecular techniques have yet to make substantial inroads into challenges at the generic and species levels.

The genus Bambusa Schreber, to which all three Australian bamboos were attributed until recently, appears to have been used as a repository for species of unknown affiliation. Ohrnberger (1999) recognized 139 species in Bambusa with a distribution centred in south Asia and extending north to Japan and south-east to the Solomon Islands and northern Australia, with an outlying species in Madagascar. The genus is demonstrably polyphyletic with at least some species of Dendrocalamus nested within it (Sun et al. 2005). Over recent decades, a considerable number of genera have been raised to accommodate obviously aberrant species or discrete groups (see brief reviews in Sun et al. 2005, Wong 2005). However, this process has proceeded in the absence of any clear definition of Bambusa, 
a problem at least partly addressed by Wong's (2005) "improving circumscription" of the genus. It remains unclear how many more nomenclatural changes are required to reduce Bambusa to coherent monophyly.

\section{Taxonomic appraisals of Australian bamboos}

After an early, chequered nomenclatural history (see Spencer 1986 for a brief summary), Queensland populations of the taxon now known as Neololeba atra were attributed to Dendrocalamus forbesii, a species described from New Guinea by Ridley (1886). Holttum (1967) transferred D. forbesii to Bambusa based on the rhachilla having distinct and equal internodes and lemmas of equal length. Whilst acknowledging its similarity to Bambusa atra, a species from New Guinea through to Sulawesi and the Philippines, Holttum considered them separable on the length of the lemma (8-10 $\mathrm{mm}$ in B. atra, 6-7 $\mathrm{mm}$ in $B$. forbesii). Widjaja (1997) argued that B. forbesii was indistinguishable from B. atra, reducing it to synonymy with the latter name taking precedence. At the same time, she described the new genus Neololeba, to which she transferred B. atra and described four new species from Indonesia. Neololeba can be distinguished from Bambusa by its simple branching system and a range of floral characteristics including pseudospikelet shape, the length of the rhachilla internodes, the absence of lodicules, and ovary shape. Neololeba also lacks the basal branches and robust, thick-walled culms of Bambusa.

Based on the original description by Mueller (1886), B. arnhemica has always been officially treated as an Australian endemic. Mueller's description was brief and although it does include a description of flowers - contrary to assertions by a number of subsequent authors including Ohrnberger (1999) - it was insufficient to ascertain the aptness of its placement in Bambusa nor to identify or exclude synonymy with Asian species. Mueller also raised the possibility that a second species occurred within the range of B. arnhemica. Franklin (2003a) found no evidence of a second species and concluded that, notwithstanding considerable discrepancies in the literature in the circumscription of Bambusa, B. arnhemica was a typical Bambusa based on pseudospikelet, floret and caryopsis features and the presence of thorns on the basal branches. The only possible discrepancy was that Bambusa species typically have lobed culm sheath auricles, but these are much reduced in B. arnhemica as they also are in B. balcooa Roxburgh (Stapleton 1994). Wong (2005) subsequently concurred with this judgement.

I also compared B. arnhemica with descriptions or illustrations of 14 other species of Bambusa known to have thorns (Franklin 2003a). Two of these, B. bambos (L.) A.Voss (syn. B. arundinacea) and B. blumeana J.H.Schultes are robust clumpers that are widely distributed (naturally and/or in cultivation) in Asia, with B. blumeana widespread in, and probably native to, Timor (Muller et al. 1998), $650 \mathrm{~km}$ north-west from the natural range of $B$. arnhemica. Most of the other species are of restricted distribution and many occur in China. Bambusa arnhemica appears to be closer to B. blumeana than B. bambos but can be distinguished from both on a number of vegetative and floral characteristics (Table 2). However, the smaller stature of $B$. arnhemica may be attributable to harsher growing conditions, and occasional clumps exceed $20 \mathrm{~m}$ in height and have culms to $13 \mathrm{~cm}$ in diameter (pers. obs.).

In providing the first description of the flowers of Bambusa moreheadiana, Clifford (1993) noted that its floral structures were consistent with the circumscription of Bambusa provided by Holttum (1967) with the exception of the number of anthers (Table 1). In contrast, Muller (2001) drew attention to a number of unusual vegetative traits of the species and 
Table 1. Taxonomic history, distribution and key morphological features of the three Australian native bamboo species.

Morphological features selected for comparison of Australian species only.

\begin{tabular}{|c|c|c|c|}
\hline & $\begin{array}{l}\text { Bambusa } \\
\text { arnhemica }\end{array}$ & Neololeba atra & $\begin{array}{l}\text { Mullerochloa } \\
\text { moreheadiana }\end{array}$ \\
\hline Original description & $\begin{array}{l}\text { Mueller (1886) as } \\
\text { B. arnhemica }\end{array}$ & $\begin{array}{l}\text { 1. Ridley (1886) } \\
\text { as Dendrocalamus } \\
\text { forbesii } \\
\text { 2. Lindley (1815) as } \\
\text { Bambusa atra - never } \\
\text { applied to Australian } \\
\text { populations }\end{array}$ & $\begin{array}{l}\text { F.M.Bailey (1889) as } \\
\text { Bambusa moreheadiana }\end{array}$ \\
\hline $\begin{array}{l}\text { Source of current } \\
\text { nomenclature }\end{array}$ & $\begin{array}{l}\text { status quo confirmed } \\
\text { by Franklin (2003a) } \\
\text { and Wong (2005) }\end{array}$ & Widjaja (1997) & Wong (2005) \\
\hline Other synonyms & - & $\begin{array}{l}\text { Bambusa forbesii } \\
\text { (Holttum 1967) } \\
\text { also Arundinaria } \\
\text { cobonii, Gigantochloa } \\
\text { novoguineensis }\end{array}$ & - \\
\hline $\begin{array}{l}\text { Australian } \\
\text { distribution }\end{array}$ & $\begin{array}{l}\text { the north-west of the } \\
\text { Northern Territory }\end{array}$ & $\begin{array}{l}\text { Queensland: } 1 . \\
\text { Mackay; 2. Daintree; } \\
\text { 3. Iron Range; } 4 . \\
\text { Torres Strait }\end{array}$ & $\begin{array}{l}\text { Queensland wet tropics: } \\
\text { populations in the } \\
\text { Daintree and Innisfail } \\
\text { regions }\end{array}$ \\
\hline $\begin{array}{l}\text { Non-Australian } \\
\text { distribution }\end{array}$ & - & $\begin{array}{l}\text { north to the } \\
\text { Philippines }\end{array}$ & - \\
\hline Habit & $\begin{array}{l}\text { robust clumper to } \\
20 \mathrm{~m}\end{array}$ & clumping, to $12 \mathrm{~m}$ & $\begin{array}{l}\text { scandent (non-twining); } \\
\text { loosely clumping }\end{array}$ \\
\hline Culms & $\begin{array}{l}\text { robust; to } 10(-12) \mathrm{cm} \\
\text { diameter; } \\
\text { internodes mostly < } \\
40 \mathrm{~cm} \text { long }\end{array}$ & $\begin{array}{l}\text { thin-walled, }<4 \mathrm{~cm} \\
\text { diameter; } \\
\text { internodes } 30-80 \mathrm{~cm} \\
\text { long }\end{array}$ & $\begin{array}{l}<4.5 \mathrm{~cm} \text { diameter; } \\
\text { internodes }<30 \mathrm{~cm} \text { long }\end{array}$ \\
\hline Branches & often $>>3$ per node & 1-3 per node & 1 to many per node \\
\hline Foliage leaves & $<20 \mathrm{~cm}$ long & $>30 \mathrm{~cm}$ long & mostly $<30 \mathrm{~cm}$ long \\
\hline Pseudospikelets & to $45(-70) \mathrm{mm}$ long & $<20 \mathrm{~mm}$ long & 5-10 mm long \\
\hline Lodicules & 3 & absent & 3 \\
\hline Anthers & 6 & 6 & 4 \\
\hline Features & $\begin{array}{l}\text { branches often } \\
\text { present near culm } \\
\text { base, thorny }\end{array}$ & $\begin{array}{l}\text { slender, thin-walled } \\
\text { culms with long } \\
\text { internodes and no } \\
\text { basal branches; large } \\
\text { leaves }\end{array}$ & $\begin{array}{l}\text { primary branches } \\
\text { often reiterate culms, } \\
\text { producing"culm } \\
\text { sequences" to } 60+\mathrm{m} \\
\text { long; branch buds in } \\
\text { contact with the ground } \\
\text { may develop rhizome-like } \\
\text { structures }\end{array}$ \\
\hline
\end{tabular}




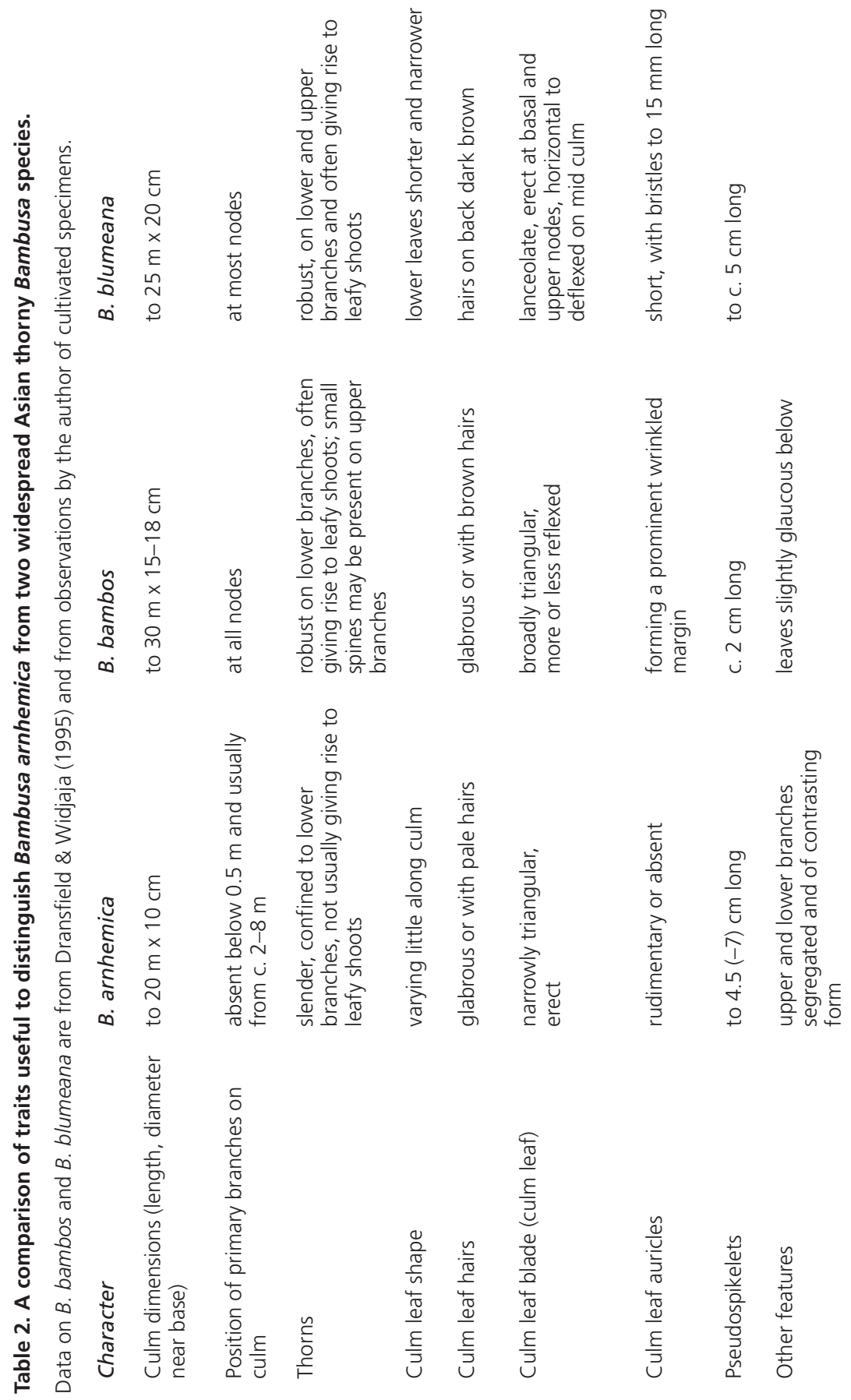


argued that it was quite unlike typical Bambusa species. Wong (2005) has since provided a thorough reappraisal of the taxon in tandem with a tighter circumscription of Bambusa, drawing attention to a range of vegetative and floral features that render it unique amongst bamboos. Noteworthy amongst these is the capacity of primary branches to reiterate culms, thus forming "culm sequences", and for branch buds in contact with the ground to develop rhizome-like structures. He placed it in the new, monotypic genus Mullerochloa, named in recognition of contribution of Len Muller, the north Queensland resident who recognised and drew attention to the uniqueness of the species. The affinities of Mullerochloa are unclear but may lie with Soejatmia K.M.Wong and Neololeba (Wong 2005).

\section{Bambusa arnhemica - an historical and biogeographic case study}

Endemicity may be interpreted as indicating that B. arnhemica has been in Australia for a long time. However, there are at least two plausible alternative hypotheses that could involve relatively recent arrival from Asia: $a$. that it is recently derived from B. blumeana in Timor or elsewhere; or $b$. that its parent population in Asia has since gone extinct. Historical and ecological perspectives provide context for considering these as yet unresolved alternatives.

The species was well-established in its current range before the arrival of Europeans, as the early European explorers found bamboo in abundance along many watercourses where B. arnhemica is known today (Table 3). The popular suggestion that Macassan trepangers introduced B. arnhemica to northern Australia from Sulawesi or nearby islands in the $18^{\text {th }}$ or $19^{\text {th }}$ centuries (White 1971) is not supported by the presence of live bamboo at Macassan camp sites or nearby springs (Macknight 1976, Bindon 1991, Mitchell 1995). In contrast, the introduced Tamarind tree Tamarindus indica L. is commonly associated with these situations. Furthermore, because trepang is most abundant in clear water, the major trepanging grounds in northern Australia were off rocky rather than mangrove-lined coasts. Thus it was that Macassan camp sites were concentrated from Cobourg Peninsula east to the Gulf of Carpentaria, and along the Kimberley coast in the west (Macknight 1973, 1976), a distribution that almost perfectly excises the coast adjacent to which B. arnhemica grows (Franklin \& Bowman 2004).

Table 3. Some early European records of bamboo in the Northern Territory.

$\begin{array}{llll}1839 & \text { John Lort Stokes } & \text { Darwin Harbour } & \text { Stokes (1846) } \\ 1845 & \text { Ludwig Leichhardt } & \text { South Alligator River } & \text { Leichhardt (1847) } \\ 1862 & \text { John McDouall Stuart } & \text { Mary and Adelaide Rivers } & \text { Stuart (1865) } \\ 1866 & \text { John McKinlay } & \begin{array}{l}\text { Margaret, McKinlay, Mary } \\ \text { Rivers and tributaries of the } \\ \end{array} & \text { McKinlay (1866) } \\ & \text { South Alligator River }\end{array}$

A plausible but hypothetical case has been made that Aboriginal people could have reached Australia on bamboo rafts (Flood 1995, Bednarik et al. 1999). The Indigenous people of northern Australia made considerable use of B. arnhemica, principally as spear shafts but also for production of didgeridoos, long-stemmed smoking pipes, ceremonial frames, water carriers, wood-carving chisels and rafts (Tindale 1925, Bindon 1991, Marrfurra et al. 1995, 
Blake et al. 1998, G. Wightman pers. comm.). Bamboo was traded extensively east into Arnhem Land, and south and south-west from the Daly River area as far as the Kimberley (Thomson 1949, Berndt \& Berndt 1988, G. Wightman pers. comm.). The Balamumu people from Caledon Bay on the east Arnhem coast, $420 \mathrm{~km}$ east of the distributional limit of B. arnhemica, specialised in the production of bamboo fighting spears (Tindale 1925). This evidence may be interpreted as suggesting long-standing cultural attachment to bamboo and thus a long period of co-existence. However, usage and cultural value need to be interpreted in the light of the demonstrable ability of Aboriginal people to rapidly adopt novel items into traditional diets and culture, as demonstrated by the fruit of the Tamarind Tamarindus indica (Mitchell 1995) and meat of Water Buffalo Bubalis bubalis (Bowman \& Robinson 2002). Interestingly, I can find no record suggesting traditional Aboriginal use of either bamboo culm shoots or seed as food, a marked contrast with the "bamboo cultures" of Asia.

I have also been unable to identify any direct archaeological evidence from Aboriginal usage that B. arnhemica may have been in Australia for millennia. Remains of bamboo have been detected in archaeological deposits in Kakadu National Park, but only in deposits no more than, and possibly much less than c. 800 years of age (Clarke 1988). The lack of earlier records may reflect that bamboo does not last long in this situation (Annie Clarke pers. comm.). The persistence and detectability of bamboo residues on stone tools (Jahren et al. 1997) offers some prospect for further exploration of archaeological deposits. There is only one possible representation of bamboo in the extensive Arnhem Land Plateau rock art record (Chaloupka 1997, p189), a painting that is only a few hundred years old (P. Giuliani pers. comm.). It depicts a man playing a didgeridoo that is banded; the banding may be decorative or could represent bamboo nodes.

Thus, though the historic record provides no evidence of a human introduction of the B. arnhemica to Australia, it does not exclude the possibility. However, several strands of ecological evidence suggest that B. arnhemica has been in Australia for a considerable period of time. The first is its primarily riparian distribution, documented in detail by Franklin and Bowman (2004) and which should be interpreted in the absence of any obvious dispersal mechanism (Franklin 2003a) and a generation time of 40-50 years (Franklin 2004). The species occurs in six major and a number of minor adjacent catchments on the Australian mainland and a restricted series of minor catchments on Melville Island. Bathymetric maps indicate that these coalesced into two palaeodrainages during the last glaciation c. 20,000 years ago: the Daly River which flowed west and then north towards Timor, and the greater Adelaide River system which drained northwards between the current tip of Cobourg Peninsula and Melville Island towards Tanimbar Island (see Voris 2000 for relevant sea-level maps). Within these catchments, the species is widely dispersed and frequently abundant from minor tributaries to the edge of coastal floodplains, but missing from the upper parts of some catchments including most notably that of the Daly River. It is consistently absent from streams with shallow, poorly-drained profiles, and from rocky stream banks. Franklin and Bowman (2004) suggested these patterns reflect infrequent dispersal across catchment boundaries to random "starting points", followed by downstream dispersal.

Overlain on this distribution is a pattern of flowering patches that range from 0.002 to $3,200 \mathrm{~km}^{2}$ (Franklin 2004). A "patch" is an area in which the majority (usually $>95 \%$ ) of B. arnhemica clumps flowered simultaneously, i.e. typically for 4-6 months from the middle of the dry season to the early wet season, adjacent patches being distinguished by flowering in a different year, or by not flowering during the period 1996-2002 when the phenomenon was studied (Franklin 2004). The arrangement of patches bears only limited resemblance 
to catchments and some patches cut across catchment or sub-catchment boundaries as if superimposed arbitrarily. Both above- and below-ground parts of B. arnhemica die after flowering, regeneration occurring solely but often prolifically from seed with seedling densities of 1,000-2,000 $\mathrm{m}^{-2}$ being observed (Franklin 2004).

The patch structure of flowering in B. arnhemica corresponds to the flowering wave phenomenon reported in many bamboos (Janzen 1976) in which, after a long period of reproductive inactivity (about 30 years in B. arnhemica), a succession of patches flower in successive years. The opportunity to document the flowering wave in B. arnhemica across much of its range and at a variety of spatial scales, a study without parallel amongst bamboos, has facilitated the generation of an hypothesis for this perplexing phenomenon. Flowering in at least some bamboos occurs at fixed though long intervals (see Kawamura 1927 for an exceptional example). It is now generally agreed to be under the control of an endogenous mechanism (a biological clock) that operates largely independently of the physiological status of the plant and which is maintained across generations by intense selection against individuals that flower out of synchrony (Janzen 1976, Simmonds 1980, Franklin 2004). The challenge has been to relate such a mechanism to the wave phenomenon. I proposed (Franklin 2004) that a wave arises from a synchronously-flowering founder population when environmentally-triggered miscounts affect a neighbourhood of plants, causing most or all of them to flower earlier or later than others of the species but without altering the genetics underlying the biological clock. A succession of miscounts generates a temporally coherent wave. It follows that, since the wave is not generated by genetic processes, the patches remain fixed out of step and are thus reproductively isolated unless a subsequent miscount by chance brings them back into alignment. The resultant allochronic isolation may well have genetic consequences and even provide the basis for speciation. The drivers of miscounts, along with the molecular mechanisms associated with such a long-term biological clock, remain unknown, although some circumstantial evidence summarised by Franklin (2004) suggests that the clock may be sensitive to fluctuations in temperature.

Given that the flowering wave remains a temporally coherent event, it seems likely to have arisen through many small chance increments rather than a few large ones. It follows that the flowering wave in B. arnhemica must have taken many generations to arise. Furthermore, it appears to have been superimposed on an established distribution.

The time scales required for $B$. arnhemica to disperse across the landscape of the northwestern Top End and to develop a complex flowering wave remain unclear. However, it is clear that many generations are required for this situation to have arisen, and at $40-50$ years per generation, B. arnhemica arrived in Australia a long time before Europeans did. I suspect also that the species arrived long before the Aborigines c. 50,000 years ago, but this remains to be demonstrated. The question is under further investigation using molecular techniques.

\section{Biogeographic hypotheses for Australian bamboos}

One possible hypothesis for the origin of Australian bamboos - that they represent a local radiation following a single founder event from Asia - a naive hypothesis that might have been tempting when all three species were attributed to Bambusa, can be confidently ruled out. Two of the taxa are Australian representatives of Asian genera, and the third is an aberrant species of uncertain affinities. 
On the current limited information, the most parsimonious biogeographic hypothesis for the occurrence of bamboos in Australia is that the three species are the products of at least three founder events from Asia (Franklin 2003b). The aptness of this perspective for B. arnhemica is particularly evident given its position within a prolific Asian genus. However, Wong (2005) has raised some plausible alternatives for Mullerochloa and Neololeba atra that warrant further consideration. There are two components to Wong's suggestions. The first is that Mullerochloa may be allied to, and derived from Neololeba, raising the possibility of a local radiation involving these two species. Given the aberrant nature of Mullerochloa, such an event may have occurred long in the past. This leads to the second component, the possibility that at least this bamboo lineage is of Gondwanan rather than Asian origin.

It is a biogeographic irony that the Bambuseae are thought to have originated in the lowland tropics of the Southern Hemisphere (Clark 1997) and yet are most prolific in Asia. Many elements of this story remain fragmentary and uncertain. Current efforts to shed light on the higher level taxonomy of the Bambuseae by the Bamboo Phylogeny Project (Iowa State University 2007), in which it is planned to include the Australian and related Asian species (K.M. Wong pers. comm.), are likely to have substantial and intriguing biogeographic implications. It is not implausible that Australia will prove to be at the centre of yet another biogeographic story to which it has long been regarded as peripheral.

\section{Acknowledgments}

As my PhD supervisor, David Bowman encouraged me to think beyond the immediate ecological and management issues at stake with $B$. arnhemica. Much of my work on B. arnhemica, including the distributional and flowering studies, was funded by the Parks \& Wildlife Commission of the Northern Territory through the foresight of David Lawson. Ron Ninnis kindly prepared the map.

\section{References}

Bailey FM (1889) Botany of the Bellenden Ker Expedition. Pp. 26,71 in Meston I (ed.) Report of the Government Scientific Expedition to the Bellender-Ker Range upon the Flora and Fauna of that part of the Colony. (Notes and Proceedings of the Legislative Assembly of Queensland Session 1889)

Bednarik RG, Hobman B \& Rogers P (1999) Nale Tasih 2: journey of a Middle Palaeolithic raft. International Journal of Nautical Archaeology 28: 25-33.

Berndt RM \& Berndt CH (1988) The World of the First Australians. Aboriginal traditional life: past and present. (Aboriginal Studies Press: Canberra)

Bindon P (1991) Ethnographic and other uses of Australian bamboo resources. Journal of the American Bamboo Society 8: 179-189.

Blake NM, Wightman G \& Williams L (1998) Iwaidja ethnobotany. Aboriginal plant knowledge from Gurig National Park, Northern Australia. (Parks and Wildlife Commission of the Northern Territory: Darwin)

Bowman DMJS \& Robinson CJ (2002) The Getting of the Nganabbarru: observations and reflections on Aboriginal buffalo hunting in northern Australia. Australian Geographer 33: 191-206.

Bystriakova N, Kapos V \& Lysenko I (2004) Bamboo biodiversity. Africa, Madagascar and the Americas. (United Nations Environment Program: Cambridge) 
Bystriakova N, Kapos V, Lysenko I \& Stapleton CMA (2003) Distribution and conservation status of forest bamboo biodiversity in the Asia-Pacific Region. Biodiversity and Conservation 12: 1833-1841.

Centre for Plant Biodiversity (2007) Australia's Virtual Herbarium (http://www.anbg.gov.au/ $\mathrm{avh} /)($ Accessed 31 October 2007)

Chaloupka G (1997) Journey in time. The world's longest continuing art tradition. The 50,000-year story of the Australian Aboriginal rock art of Arnhem Land. (Reed: Kew, Victoria)

Clark LG (1997) Bamboos: the centrepiece of the grass family. Pp. 237-250 in Chapman GP (ed.) The bamboos. (Academic Press: London)

Clarke A (1988) Archaeological and ethnobotanical interpretations of plant remains from Kakadu National Park, Northern Territory. Pp. 123-136 in Meehan B \& Jones R (eds) Archaeology with ethnography: an Australian perspective. (Australian National University: Canberra)

Clifford HT (1993) Bambusa moreheadiana F.M. Bailey (Magnoliophyta: Poaceae). Austrobaileya 4: 131-133.

Cusack V (1999) Bamboo world. The growing and use of clumping bamboos. (Kangaroo Press: Sydney)

Dransfield S \& Widjaja EA (eds) (1995) Plant Resources of South-east Asia. No. 7. Bamboos. (Backhuys Publishers: Leiden)

Flood J (1995) Archaeology of the Dreamtime. The story of prehistoric Australia and its people. (Angus \& Robertson: Sydney)

Franklin DC (2003a). Morphology and taxonomy of the Top End Bamboo Bambusa arnhemica F. Muell., a little-known bamboo from northern Australia. Bamboo Science and Culture 17: $44-54$.

Franklin DC (2003b) Bamboo and the northern Australian connection. Flora Malesiana Bulletin 13: 275-277.

Franklin DC (2004) Synchrony and asynchrony: observations and hypotheses for the flowering wave in a long-lived semelparous bamboo. Journal of Biogeography 31: 773-786.

Franklin DC \& Bowman DMJS (2003) Bamboo, fire and flood: regeneration of Bambusa arnhemica (Bambuseae: Poaceae) after mass-flowering and die-off at contrasting sites in monsoonal northern Australia. Australian Journal of Botany 51: 529-542.

Franklin DC \& Bowman DMJS (2004) A multi-scale biogeographic analysis of Bambusa arnhemica, a bamboo from monsoonal northern Australia. Journal of Biogeography 31: 1335-1353.

Grass Phylogeny Working Group (2001) Phylogeny and subfamilial classification of the grasses (Poaceae). Annals of the Missouri Botanical Gardens 88: 373-457.

Griscom BW, Daly DC \& Ashton MS (2007) Floristics of bamboo-dominated stands in lowland terra-firma forests of southwestern Amazonia. Journal of the Torrey Botanical Society 134: 108-125.

Holttum RE (1967) The bamboo of New Guinea. Kew Bulletin 21: 263-292.

Holz CA \& Veblen TT (2006) Tree regeneration responses to Chusquea montana bamboo dieoff in a sub-alpine Nothofagus forest in the southern Andes. Journal of Vegetation Science 17: 19-28.

Iowa State University (2007) Bamboo biodiversity (http://www.eeob.iastate.edu/research/ bamboo/index.html) (Accessed 31 October 2007)

Jahren AH, Toth N, Schick K, Clark JD \& Amundson RG (1997) Determining stone tool use: chemical and morphological analyses of residues on experimentally manufactured stone tools. Journal of Archaeological Science 24: 245-250.

Janzen DH (1976) Why bamboos wait so long to flower. Annual Review of Ecology and Systematics 7: 347-391.

Judziewicz EJ, Clark LG, Londoño X \& Stern MJ (1999) American bamboos. (Smithsonian Institution Press: Washington DC)

Kawamura S (1927) On the periodical flowering of the bamboo. Japanese Journal of Botany 3: 335-349. 
Lazarides M (2002) Economic attributes of Australian grasses. Pp. 213-244 in Mallett K \& Orchard AE (eds) Flora of Australia, vol. 43. (Australian Biological Resources Study \& CSIRO: Melbourne)

Leichhardt L (1847) Journal of an Overland Expedition in Australia, from Moreton Bay to Port Essington, a distance of upwards of 3000 miles, during the years 1844-1845. (T \& W Boone: London)

Leu A (2001) New location for Neololeba atra (Lindl.) Widjaja. Bamboo Society of Australia Newsletter 3: 10-12.

Lindley J (1815) The Penny Cyclopaedia of the Society for the Diffusion of Useful Knowledge 3: 357 .

Macknight CC (1973) The nature of early maritime trade: some points of analogy from the eastern part of the Indonesian archipelago. World Archaeology 5: 198-209.

Macknight CC (1976) The voyage to Marege. Macassan trepangers in northern Australia. (Melbourne University Press: Melbourne)

Mallett K \& Orchard AE (eds) (2002) Poaceae I. Introduction and Atlas. Flora of Australia, vol. 43. (Australian Biological Resources Study \& CSIRO: Melbourne)

Marrfurra P, Akanburru M, Wawul M, Kumunerrin T, Adya H, Kamarrama K, Kanintyanyu M, Waya T, Kannyi M, Wightman G \& Williams, L (1995) Aboriginal plant use from the Daly River area, Northern Australia. Northern Territory Botanical Bulletin 22: 1-112.

McKinlay J (1866) J. McKinlay's Northern Territory explorations, 1866. (Government Printer: Adelaide)

Mitchell S (1995) A transient heritage: trepanging sites on the Cobourg Peninsula. Historic Environment 11: 37-46.

Mueller BV (1886) New Australian Plants. Australasian Journal of Pharmacy 1: 447.

Muller L (2001) Bambusa Moreheadiana - It's not a Bambusa. Bamboo Society of Australia Newsletter 3: 13-17.

Muller L, Hull G \& Sherlock K (1998) Bamboos in Timor. Studies in languages and cultures of East Timor 1: 52-68.

Ohrnberger D (1999) The bamboos of the world: annotated nomenclature and literature of the species and the higher and lower taxa. (Elsevier: Amsterdam)

Ridley HN (1886) On the monocotyledonous plants of New Guinea collected by Mr. H. O. Forbes. Journal of Botany, British and Foreign, London 24: 321-327, 353-360.

Saitoh T, Seiwa K \& Nishiwaki A (2002) Importance of physiological integration of dwarf bamboo to persistence in forest understorey: a field experiment. Journal of Ecology 90: 78-85.

Simmonds NW (1980) Monocarpy, calendars and flowering cycles in angiosperms. Kew Bulletin 35: 235-245.

Spencer R (1986) Australian bamboos. Australian Bamboo Network Newsletter 2: 8-11.

Stapleton CMA (1994) The bamboos of Nepal and Bhutan Part I: Bambusa, Dendrocalamus, Melocanna, Cephalostachyum, Teinostachyum, and Pseudostachyum (Gramineae: Poaceae, Bambusoideae). Edinburgh Journal of Botany 51: 1-32.

Stokes JL (1846) Discoveries in Australia; with an account of the coasts and rivers explored and surveyed during the voyage of H.M.S. Beagle in the years 1837-38-39-40-41-42-43. (Libraries Board of South Australia (facsimile edition, 1969): Adelaide)

Stuart JM (1865, facsimile 1984) Explorations in Australia. The journals of John McDouall Stuart during the years 1858,1859,1860,1861, \& 1862, when he fixed the centre of the continent and successfully crossed it from sea to sea. (Hesperian Press: Carlisle, Western Australia)

Sun Y, Xia NH \& Lin R (2005) Phylogenetic analysis of Bambusa (Poaceae : Bambusoideae) based on internal transcribed spacer sequences of nuclear ribosomal DNA. Biochemical Genetics 43: 603-612.

Taylor AH, Huang JY \& Zhou SQ (2004) Canopy tree development and undergrowth bamboo dynamics in old-growth Abies-Betula forests in Southwestern China: a 12-year study. Forest Ecology and Management 200: 347-360. 
Thomson DF (1949) Economic structure and the ceremonial exchange cycle in Arnhem Land. (MacMillan \& Co.: Melbourne)

Tindale NB (1925) Natives of Groote Eylandt and of the west coast of the Gulf of Carpentaria. Records of the South Australian Museum 3: 61-102.

Triplett JK, Weakley AS \& Clark LG (2006) Hill cane (Arundinaria appalachiana), a new species of bamboo (Poaceae: Bambusoideae) from the southern Appalachian mountains. Sida 22: 79-95.

Voris HK (2000) Maps of Pleistocene sea levels in Southeast Asia: shorelines, river systems and time durations. Journal of Biogeography 27: 1153-1167.

White PJ (1971) New Guinea and Australian prehistory: the 'Neolithic Problem'. Pp. 182-195 in Mulvaney DJ \& Golson J (eds) Aboriginal man and environment in Australia. (Australian National University Press: Canberra)

Widjaja EA (1997) New taxa in Indonesian bamboos. Reinwardtia 11: 57-152.

Wong KM (2005) Mullerochloa, a new genus of bamboo (Poaceae : Bambusoideae) from northeast Australia and notes on the circumscription of Bambusa. Blumea 50: 425-441.

Worobiec E \& Worobiec G (2005) Leaves and pollen of bamboos from the Polish Neogene. Review of Palaeobotany and Palynology 133: 39-50.

Zhang W \& Clark LG (2000) Phylogeny and classification of the Bambusoideae (Poaceae). Pp. 35-42 in Jacobs SWL \& Everett J (eds) Grasses: systematics and evolution. (CSIRO: Melbourne)

Manuscript received 06 November 2007, accepted 01 April 2008 